18. Mascia L., Grasso S., Fiore T. et al. Cerebro-pulmonary interactions during the application of low levels of positive end-expiratory pressure. Intensive Care Med. 2005. Vol. 31. P. 373-379. https://doi.org/ 10.1007/s00134-004-2491-2

19. Namen A.M., Ely E.W., Tatter S.B. et al. Predictors of successful extubation in neurosurgical patients. Am J Respir Crit Care Med. 2001. Vol. 163(3 Pt 1). P. 658-64.

20. Asehnoune K., Seguin P., Lasocki S. et al. Extubation Success Prediction in a Multicentric Cohort of Patients with Severe Brain Injury. Critical Care Medicine. 2017. Vol. 127. P. 338-346.

DOI https://doi.org/10.30525/978-9934-588-81-5-1.34

\title{
ЦЕРЕБРАЛЬНА ГЕМОДИНАМІКА У ДІТЕЙ $З$ АПХ ЗА ДАНИМИ УЛЬТРАЗВУКОВОЇ ДОПЛЕРОГРАФІЇ СУДИН ГОЛОВНОГО МОЗКУ
}

\author{
Кулешов О. В. \\ кандидат медичних наук, \\ дочент кафедри пропедевтики дитячих хвороб \\ з доглядом за хворими дітьми
}

Вінницький національний медичний університет імені М. I. Пирогова

Медражевська Я. А.

кандидат медичних наук,

дочент кафедри пропедевтики дитячих хвороб

з доглядом за хворими дітьми

Вінницький національний медичний університет імені М. І. Пирогова

Черепахіна Л. П.

кандидат медичних наук,

дочент кафедри пропедевтики дитячих хвороб

з доглядом за хворими дітьми

Вінницький національний медичний університет імені М. І. Пирогова

Фік Л. О.

кандидат медичних наук,

дочент кафедри пропедевтики дитячих хвороб

з доглядом за хворими дітьми

Вінницький національний медичний університет імені М. І. Пирогова 


\section{Чигір I. B. \\ кандидат медичних наук, асистент кафедри пропедевтики дитячих хвороб \\ з доглядом за хворими дітьми \\ Вінницький національний медичний університет імені М. І. Пирогова м. Вінниця, Украӥна}

У практиці педіатра і дитячого кардіолога часто зустрічаються малі серцеві аномалії серця, які в літературі згадуються у вигляді аномально розташованих трабекул, «помилкових» або додаткових хорд в лівому шлуночку, аномалій будови папілярних (сосочкових) м'язів, пролапсів мітрального клапана [1]. Вони не призводять до формування вад і порушень кровообігу, але часто дають специфічну картину на УЗД. Діти з подібними особливостями ростуть і розвиваються не відрізняючись від своїх однолітків. Вони не страждають від будь-яких проблем на протязі життя, або по досягненню підліткового віку можуть почати скаржитися на минущі болі в області грудної клітини, слабкість. Досить часто ці скарги виникають не з самим серцем і його особливостями, а з роботою вегетативної системи.

Багато дослідників вважають порушення вегетативного тонусу самостійним захворюванням, часто не зважаючи на те, що він може бути і проявом системного дефекту біологічних мембран, який виявляється в особливостях розвитку сполучно-тканинної дисплазії [2] і розвитку центральних, периферичних нервових рецепторів.

Ціллю нашого дослідження був аналіз мозкової гемодинаміки за допомогою ультразвукової доплерографії (УЗДГ) судин головного мозку у дітей з аномально прикріпленими хордами (АПХ).

Проведено обстеження 64 дітей з АПХ у віці від 13 до 17 років, які склали основну групу. Результати дослідження порівнювались 3 даними групи контролю, в яку ввійшли 23 практично здорових дитини також 13-17 років. Дослідження проводилось на базі відділення старшого дитинства МЛ “Центр Матері та Дитини” м. Вінниці. Усім дітям проводилась ультразвукова доплерографія екстра- та інтракраніальних судин та вен головного мозку на апараті «Kranzbuhler logitop 5» (Німеччина) з частотою датчиків 8 та $2 \mathrm{Mhz} 3$ оцінкою: 1) індексу резистентності (Ri), 2) систоло-діастолічний індексу (Sd), 3) максимальної систолічної швидкісті (Vs), 4) максимальної діастолічної швидкості (Vd) в загальній сонній (Аcc), екстракраніальній частині внутрішньої сонної (Aci), сифонах внутрішної сонної (Siphoni Aci), наблокових (supratrochlearis), хребтових (vertebralis) та основній артеріях 
(basillaris). Венозний відтік враховував тільки візуальний аналіз спектограм по яремних венах (v.jugularis). Залежності показників від віку та статі в даному методі дослідження не існує.

Нами було виявлено порушення кровотоку за результатами УЗДГ у дітей з АПХ. Так, відзначалась тенденція до зниження систолічної та діастолічної швидкостей по a.vertebralis 3 обох боків 3 підвищенням $\mathrm{Sd}$ відносно групи контролю, що вказує на підвищення їх еластичності та зниження тонусу. Дані зміни призвели до перерозподілу кровотоку по основній артерії із зменшенням (p $\square 0,05) \mathrm{Ri}$ та 3 тенденцією до зниження Sd. Це свідчить про зниження іï еластичності та підвищення тонусу судин із збереженим периферичним опором дистальніше від іiї ходу.

Тенденція до зниження систолічної швидкості 3 достовірним зниженням діастолічної швидкості кровотоку $(\mathrm{p} \square 0,05)$ по загальній сонній артерії з обох боків характеризується зменшенням іiї тонічних властивостей. Однак, враховуючи нормативність показників Ri та недостовірне збільшення $\mathrm{Sd}$ відносно групи контролю, можна говорити про тенденцію до підвищення іï еластичних властивостей (Таблиця 1).

Таблиця 1

Гемодинамічні показники у дітей з АПХ

\begin{tabular}{|c|c|c|c|c|c|}
\hline \multirow{3}{*}{$\begin{array}{l}\text { По- } \\
\text { каз- } \\
\text { ник }\end{array}$} & \multirow[b]{3}{*}{ Артерія } & \multicolumn{4}{|c|}{ Парні судини } \\
\hline & & \multicolumn{2}{|c|}{ Права сторона } & \multicolumn{2}{|c|}{ Ліва сторона } \\
\hline & & $\begin{array}{c}\text { Основна } \\
\text { група } \\
\text { n=64 }\end{array}$ & $\begin{array}{c}\text { Група } \\
\text { контролю } \\
\mathbf{n}=\mathbf{2 3}\end{array}$ & $\begin{array}{c}\text { Основна } \\
\text { група } \\
\text { n=64 }\end{array}$ & $\begin{array}{c}\text { Група } \\
\text { контролю } \\
\mathbf{n}=23 \\
\end{array}$ \\
\hline \multirow{2}{*}{$\mathrm{Ri}$} & Acc & $0,74 \pm 0,01$ & $0,69 \pm 0,21$ & $0,74 \pm 0,01$ & $0,64 \pm 0,02$ \\
\hline & Vertebralis & $0,73 \pm 0,02$ & $0,70 \pm 0,02$ & $0,730,02$ & $0,70 \pm 0,04$ \\
\hline \multirow{2}{*}{$\mathrm{Sd}$} & Acc & $4,8 \pm 0,24$ & $3,00 \pm 0,24$ & $6,77 \pm 0,24$ & $2,80 \pm 0,13$ \\
\hline & Vertebralis & $6 \pm 0,6$ & $3,75 \pm 0,35$ & $6 \pm 0,56^{*}$ & $3,7 \pm 0,4$ \\
\hline \multirow{2}{*}{ Vs } & Acc & $85,21 \pm 4,21$ & $86,3 \pm 4,9$ & $85,2 \pm 4,21$ & $85,1 \pm 4,6$ \\
\hline & Vertebralis & $23,7 \pm 1,3^{*}$ & $31,9 \pm 3,1$ & $23,73 \pm 1,3^{*}$ & $34,1 \pm 3,5$ \\
\hline \multirow{2}{*}{$\mathrm{Vd}$} & Acc & $22,8 \pm 2,02 *$ & $31,8 \pm 3,1$ & $22,76 \pm 2,02 *$ & $32,1 \pm 2,5$ \\
\hline & Vertebralis & $6,5 \pm 0,5^{*}$ & $9,9 \pm 1,7$ & $6,54 \pm 0,53^{*}$ & $10,00 \pm 0,86$ \\
\hline \multicolumn{6}{|c|}{ Непарні судини (a. Basillaris) } \\
\hline & \multicolumn{3}{|c|}{ Основна група, $\mathrm{n}=64$} & \multicolumn{2}{|c|}{ Група контролю, $\mathrm{n}=23$} \\
\hline $\mathrm{Ri}$ & \multicolumn{3}{|c|}{$0,51 \pm 0,01$} & \multicolumn{2}{|c|}{$0,56 \pm 0,04$} \\
\hline $\mathrm{Sd}$ & \multicolumn{3}{|c|}{$2,10 \pm 0,03$} & \multicolumn{2}{|c|}{$2,60 \pm 0,21$} \\
\hline Vs & \multicolumn{3}{|c|}{$48,58 \pm 1,24^{*}$} & \multicolumn{2}{|c|}{$43,60 \pm 2,97$} \\
\hline $\mathrm{Vd}$ & \multicolumn{3}{|c|}{$23,73 \pm 0,62$} & \multicolumn{2}{|c|}{$23,9 \pm 3,5$} \\
\hline
\end{tabular}

Примітка: зірочкою (*) позначено достовірні відмінності відносно групи контролю $\left(p^{*} 0,05\right)$ 
Виявлені зміни кровотоку у дітей з малими серцевими аномаліями свідчать про зниження кровотоку по хребтових артеріях 3 перерозподілом кровотоку у вигляді його збільшення по основній артерії. Дані зміни пов'язані з рефлекторною авторегуляцією судинного тонусу у відповідь на порушення вегетативного гомеостазу.

Аналізуючи венозний кровотік у дітей $з$ малими серцевими аномаліями, встановлено таку структуру порушень по v.jugularis: $з$ права $\epsilon$ домінуюче порушення венозного відтоку у вигляді якісних змін спектрограми над лівою (37,5 та 21,8\% відповідно).

Отже, враховуючи вищенаведені результати, мозковий кровотік, за даними УЗДГ дослідження, можна вважати задовільним у дітей 3 АПХ. Зміни 3 боку еластико-тонічних властивостей судин можна пов'язати з порушенням вегетативного балансу.

\title{
Література:
}

1. Гнусаев С.Ф., Белозеров Ю.М., Виноградов А.Ф. Клиническое значение малых аномалий сердца у детей. Медицинский вестник северного Кавказа. 2008; 2: 39-43.

2. Вейн А.М. ред. Вегетативные расстройства: Клиника, диагностика, лечение. М.: МИА, 2000. 752 с.

DOI https://doi.org/10.30525/978-9934-588-81-5-1.35

\section{DELAUNAY TRIANGULATION, VORONOI DIAGRAMS, CONVEX ANALYSIS AS BASIS FOR OPIMIZATION OF HEART ELECTRICAL INSTABILITY DIAGNOSIS}

\author{
Kulishov S. K. \\ Doctor of Medical Sciences, Candidate of Medical Sciences, \\ Professor at the Department of the Internal Medicine № 1 \\ Ukrainian Medical Stomatological Academy \\ Poltava, Ukraine
}

Introduction. Different technologies were used for analysis of heart electrical instabilities [1, 2, 3, 4, 5], but individual diagnosis by Delaunay triangulation, Voronoi Diagrams methods remain actual for cardiology $[1,2,3,4,5]$. The quality of heart arrhythmia and conduction disturbances diagnosis is derived by individual etiological and pathogenetic features $[1,2,3,4,5]$. Qualitative and quantitative characteristics of 2D, 3D electrocardiograms in the patients with pirouette ventricular pair extrasystoles gave us possibilities to determine peculiarities of oxymoron, 